\title{
Stability indicating method development \& validation on RP- UPLC for simultaneous estimation of levofloxacin and ornidazole in their combine dosage form
}

\author{
Sevak Manan R*1, Patel Nirav B ${ }^{2}$, Patel Kamlesh ${ }^{3}$, Desai Hemant $\mathrm{T}^{4}$ \\ ${ }^{*}$ Assistant Professor at Ganpat University, Mehsana, Kherva, Gujarat, India. \\ ${ }^{2}$ Nirlife Healthcare (Healthcare Division of Nirma), Ahemdabad, Gujrat, India. \\ ${ }^{3}$ Virgo Uap Pharma Pvt. Ltd., Ahmedabad, Gujarat, India. \\ ${ }^{4}$ PhD Guide, Kadi University, Gandhinagar, Gujarat, India.
}

\begin{abstract}
This research manuscript explains simple yet sensitive \& speedy, accurate, precise, repeatable \& reproducible RP-UPLC method for the analysis of Levofloxacin and Ornidazole in combine pharmaceutical dosage form. The sample was analyzed by reverse phase C18 column (Purospher Star 100 $\times 2.1 \mathrm{~mm}$, Merck Specialities) as stationary phase and Phosphate Buffer: Acetonitrile $(65: 35 \mathrm{v} / \mathrm{v})$ as a mobile phase [where $P^{H}$ of of the buffer was adjusted to 2.5 by using Tri ethylamine (1ml for 1 lit buffer) and ortho-phosphoric acid] at a flow rate of $0.44 \mathrm{ml} / \mathrm{min}$. TUV detector was used for the detection at $294 \mathrm{~nm}$. The retention time for Levofloxacin and Ornidazole was found to be 0.537 and 0.938 minute respectively. The linearity for both the drugs was obtained in the concentration range of 2-14 $\mu \mathrm{g} / \mathrm{ml}$ and $4-28 \mu \mathrm{g} / \mathrm{ml}$. The method was successfully applied to pharmaceutical formulation because no significant interferences from suspension excipient were found. The method retained its accuracy and precision when certain variations in method parameters were applied.
\end{abstract}

Keywords: Combined dosage forms; Levofloxacin and Ornidazole; Method development \& validation, RPUPLC,Stability Study.

\section{Introduction}

The combination of Levofloxacin and Ornidazole is a synthetic chemotherapeutic antibiotic of the fluoroquinolone drug class and is used to treat severe of life threatening bacterial infections which have failed to respond to other antibiotic classes. It is sold under various brand names, such as Levaquin and Tavanic. Levofloxacin is an antibiotic that stops multiplication of bacteria by preventing the reproduction and repair of their genetic material, DNA. Levofloxacin is chemically a chiral fluorinated carboxyquinolone, is the pure (-) (S)-enantiomer of the racemic drug substance ofloxacin. The chemical name is (-)-(S)-9-fluoro2,3-dihydro-3methyl-10-(4-methyl-1-piperazinyl)-7-oxo-7H-pyrido[1,2,3-de]-1,4benzoxazine-6-carboxylic acid hemihydrate. (fig. 1) and Ornidazole is useful for some protozoan infections and mainly used in poultry industry. Chemically it is $\alpha$-(Chloromethyl)-2-methyl-5-nitro-1H-imidazole-1-ethanol; 1-(3-Chloro-2-hydroxypropyl)-2-methyl-5nitroimidazole; Madelen; NSC 95075; Ornidal; Ro 7-0207; Tiberal (fig. 2).

Figure 1: Chemical structure of levofloxacin<smiles>C[C@H]1COc2c(N3CCN(C)CC3)c(F)cc3c(=O)c(C(=O)O)cn1c23</smiles>

Figure 2: Chemical structure of Ornidazole<smiles>Cc1ncc([N+](=O)[O-])n1CC(O)CCl</smiles>

Literature search reveals that various analytical methods like HPTLC ${ }^{[1]}, \operatorname{HPLC}^{[2,3]}$ and Spectroscopy ${ }^{[3,4]}$ are available for the estimation of Levofloxacin and Ornidazole in combine dosage form. There is no reported method for estimation of Levofloxacin and Ornidazole in their combined dosage form by RP-UPLC. This encouraged the present work. The method was developed and validated as per ICH ${ }^{[5,6 \& 7]}$ and usp ${ }^{[8]}$ guideline. The aim of present work is to develop a simple yet rapid, accurate and precise RP-UPLC method for estimation of Levofloxacin and Ornidazole in their combine marketed formulation which is more efficient method than the RP-HPLC method. 


\section{Reagents And Materials}

Levofloxacin and Ornidazole standards were obtained from Nirlife, Healthcare division of Nirma. Ahmedabad, Gujarat, India. The combination product M LEVO-OZ Suspension was procured from market. Acetonitrile (HPLC grade from Finar Reagent, Ahemedabad, India), $\mathrm{KH}_{2} \mathrm{PO}_{4}$, Tri ethyl amine and ortho phosphoric acid (acquired form FINAR chemicals Pvt. Ltd., Ahmedabad, India) was used in the study. High purity Water for injection was used in the study.

\section{Instruments And Condition}

The fast liquid chromatography was performed using waters' UPLC system with TUV detector. Chromatogram and data were recorded using Empower 2 software. Separation was achieved by Purospher Star C18 column $(100 \mathrm{~mm} \times 2.1 \mathrm{~mm}$ id, $2 \mu \mathrm{m}$ particle size, Merck, Germany) as a stationary phase with Phosphate Buffer: Acetonitrile $(65: 35 \mathrm{v} / \mathrm{v})$ as a mobile phase at a flow rate of $0.44 \mathrm{ml} / \mathrm{min}$, Injection volume is $1 \mu \mathrm{l}$ and detection wavelength was $294 \mathrm{~nm}$ in TUV detector. Column temperature was $50^{\circ} \mathrm{C}$ and Sample temperature was taken $20^{\circ} \mathrm{C}$. Weigh machine of Essetoreka company, model AR- 2140, Ph meter of Systronics company, model 362 and sonicator of Toshcon company, model SW1 were used in the study.

\section{Preparation Of Mobile Phase}

$6.8 \mathrm{gm} \mathrm{KH}_{2} \mathrm{PO}_{4}$ was weighed accurately in $1000 \mathrm{~mL}$ volumetric flask. To it about $100 \mathrm{~mL}$ of Water is added, sonicated and further make up the volume up to mark with water [and $\mathrm{P}^{\mathrm{H}}$ of the buffer is adjusted to 2.5 by Triethylamine ( $1 \mathrm{ml} /$ lit of buffer solution) and ortho-phosperic acid], from the prepared buffer solution $650 \mathrm{ml}$ is mixed with $350 \mathrm{ml}$ of actonitrile in $1000 \mathrm{ml}$ volumetric flask to make a mobile phase ratio buffer: acetonirile $65: 35 \% \mathrm{v} / \mathrm{v}$ respectively. This mobile phase was used as diluents \& also was used throughout study.

\section{Preparation Of Standard Stock Solution}

An accurately weighed Levofloxacin $(10 \mathrm{mg})$ and Ornidazole $(20 \mathrm{mg})$ were transferred into two different $200 \mathrm{~mL}$ volumetric flask, dissolved in $200 \mathrm{~mL}$ mobile phase produce concentration of Levofloxacin $(50 \mu \mathrm{g} / \mathrm{ml})$ and Ornidazole $(100 \mu \mathrm{g} / \mathrm{ml})$.

\section{Preparation Of Mixed Standard Working Solution}

Accurately weighed Levofloxacin $(10 \mathrm{mg})$ and Ornidazole $(20 \mathrm{mg})$ were transferred to $200 \mathrm{~mL}$ volumetric flask, dissolved in $200 \mathrm{~mL}$ mobile phase to produce concentration of Levofloxacin $(50 \mu \mathrm{g} / \mathrm{ml})$ and Ornidazole $(100 \mu \mathrm{g} / \mathrm{ml})$.

Fig.3 linearity of Levofloxacin

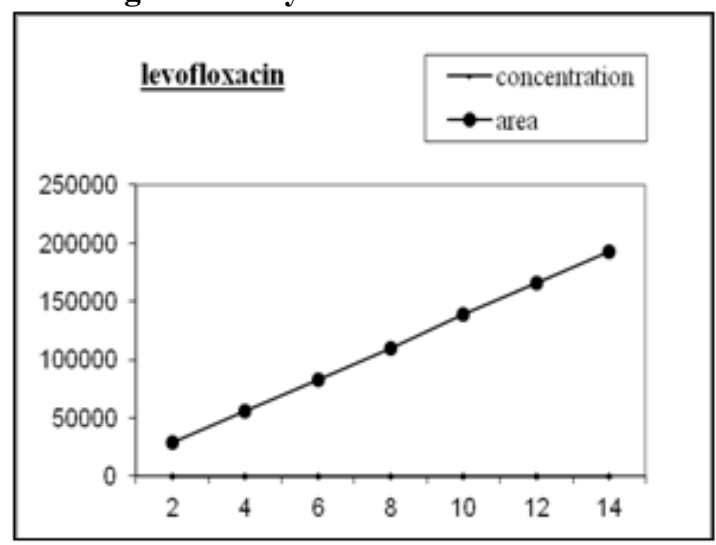

Fig.: 4 linearity of Ornidazole

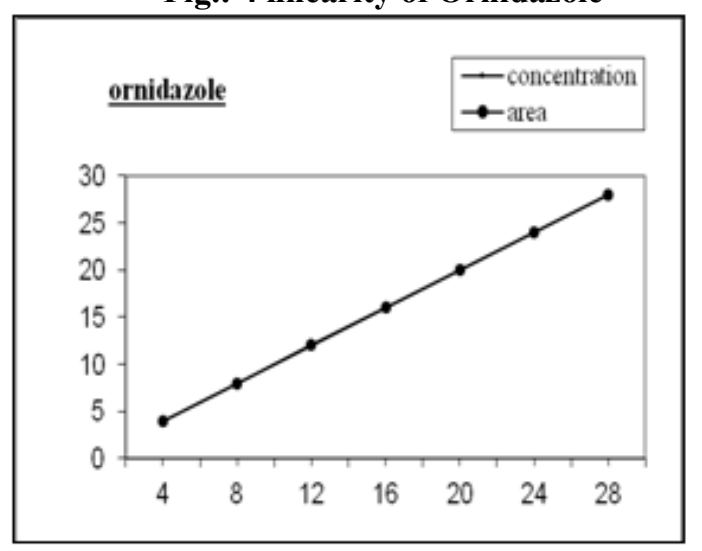

\section{Preparation Of Calibration Curve}

Aliquots $(1.25,2.5,5.0,7.5,10.0 \& 12.5 \mathrm{ml})$ of mixed standard working solutions (equivalent to $2.5,5,10,15,20 \& 25 \mu \mathrm{g} / \mathrm{ml}$ Levofloxacin and 5,10,20,30,40 and $50 \mu \mathrm{g} / \mathrm{ml}$ of Ornidazole, each) were transferred in a series of $25 \mathrm{ml}$ volumetric flasks, and the volume was made up to the mark with mobile phase. Each solution was injected by following the previously described chromatographic condition and responses were recorded. Calibration curves were constructed by plotting the peak areas versus the concentration (fig. $3 \& 4$ ), each response was average of three determinations. 


\section{Method Precision (Repeatability)}

The precision of the method was checked by repeatedly injecting $(\mathrm{n}=6)$ injections of Levofloxacin (10ppm): Ornidazole (20ppm) without changing the parameters.

\section{Accuracy (Recovery Study)}

The accuracy of the method was determined by calculating the recoveries of Levofloxacin and Ornidazole by the standard addition method. Known amounts of standard solutions of Levofloxacin and Ornidazole were added at $80 \%, 100 \%$ and $120 \%$ level to pre -quantified sample solutions of Levofloxacin and Ornidazole (10 and $20 \mu \mathrm{g} / \mathrm{ml}$ respectively). The amounts of Levofloxacin and Ornidazole were estimated by applying obtained values to the respective regression line equations.

\section{Preparation Of Marketed Sample Solution For Assay}

For determination of the assay of Levofloxacin and Ornidazole in combine marketed formulation, $\mathrm{M}$ LEVO-OZ Suspension, Lable claim : levofloxacin- $125 \mathrm{mg} / 10 \mathrm{ml}$ and ornidazole- $250 \mathrm{mg} / 10 \mathrm{ml}$ was taken. From this suspension $2 \mathrm{ml}$ solution was taken and transferred to $50 \mathrm{~mL}$ volumetric flask, dissolved in mobile phase and sonicated for $30 \mathrm{~min}$. Then the solution was filtered through Whatmann filter paper No. 41 and residue was washed with mobile phase \& the solution was diluted up to the mark with mobile phase. From this solution, accurately measured $1.0 \mathrm{~mL}$ of solution was transferred to $50 \mathrm{~mL}$ volumetric flask, diluted up to the mark with mobile phase to get final working concentration of Levofloxacin $(10 \mu \mathrm{g} / \mathrm{ml})$ and Ornidazole $(20 \mu \mathrm{g} / \mathrm{ml})$. A sample solution was injected under the operating chromatographic condition as described above and responses were recorded. The analysis procedure was repeated three times with suspension formulation.

\section{Intermediate Precision (Reproducibility)}

The intraday precision of the proposed method was determined by estimating the corresponding responses for 3 different concentrations in a same day in morning, evening and night.

The interday precision was determined by estimating the corresponding responses for 3 different concentrations in 3 different (alternative) days of a week in morning, evening and night.

Different concentrations taken for Levofloxacin $(8,10$ and $12 \mu \mathrm{g} / \mathrm{ml})$ and Ornidazole $(16,20$ and $24 \mu \mathrm{g} / \mathrm{ml})$.

Table 1: Regression analysis data and summary of validation parameter for the proposed RP-UPLC method

\begin{tabular}{|c|c|c|}
\hline \multicolumn{3}{|c|}{ method } \\
\hline \multirow[t]{2}{*}{ Parameters } & \multicolumn{2}{|c|}{ RP-UPLC method } \\
\hline & Levofloxacin & Ornidazole \\
\hline Concentration range $(\mu \mathrm{g} / \mathrm{ml})$ & $2-14$ & $4-28$ \\
\hline Slope & 13719.97 & 3311.65 \\
\hline Intercept & 742.38 & -192.05 \\
\hline Correlation coefficient & 1.0000 & 0.9999 \\
\hline $\operatorname{LOD}^{\mathrm{a}}(\mu \mathrm{g} / \mathrm{ml})$ & 0.122 & 0.221 \\
\hline $\mathrm{LOQ}^{\mathrm{b}}(\mu \mathrm{g} / \mathrm{ml})$ & 0.370 & 0.671 \\
\hline Accuracy & $99.95 \%$ & $99.89 \%$ \\
\hline Repeatability $\left(\% \mathrm{RSD}^{\mathrm{C}}, \mathrm{n}=6\right)$ & 0.219 & 0.211 \\
\hline Intraday $(n=3)\left(\% R^{2} D^{C}\right)$ & 0.563 & 0.784 \\
\hline Interday $(n=3)\left(\% \mathrm{RSD}^{\mathrm{C}}\right)$ & 0.448 & 0.627 \\
\hline
\end{tabular}

$a=$ Limit of Detection, $b=$ Limit of Quantitation, $c=$ relative standard deviate

Table 2: Recovery data for the proposed method

\begin{tabular}{|l|l|l|l|l|}
\hline Drug & Level & $\begin{array}{l}\text { Amount of sample taken } \\
(\boldsymbol{\mu g} / \mathbf{m l})\end{array}$ & $\begin{array}{l}\text { Amount of standard } \\
\text { spiked (\%) }\end{array}$ & $\begin{array}{l}\text { Mean } \\
\text { \%Recovery S.D.(n=6) }\end{array}$ \\
\hline \multirow{3}{*}{ Levofloxacin } & I & 8 & $80 \%$ & 100.13 \\
\cline { 2 - 5 } & II & 10 & $100 \%$ & 101.08 \\
\cline { 2 - 5 } & III & 12 & $120 \%$ & 100.81 \\
\hline \multirow{3}{*}{ Ornidazole } & I & 16 & $80 \%$ & 99.91 \\
\cline { 2 - 5 } & II & 20 & $100 \%$ & 100.04 \\
\cline { 2 - 5 } & III & 24 & $120 \%$ & 99.96 \\
\hline
\end{tabular}

Table 3: System suitability test

\begin{tabular}{|l|l|l|}
\hline Parameters & $\begin{array}{l}\text { Levofloxacin } \\
(\mathbf{n = 6})\end{array}$ & $\begin{array}{l}\text { Ornidazole } \\
(\mathbf{n}=\mathbf{6})\end{array}$ \\
\hline Retention time (min) & 0.537 & 0.938 \\
\hline Tailing factor & 0.99 & 0.83 \\
\hline Theoretical plates & 2222.6 & 5732.0 \\
\hline Resolution & 8.85 & \\
\hline
\end{tabular}


Stability indicating method development \& validation on RP-UPLC for simultaneous estimation ....

Table 4: Analysis of marketed formulation of levofloxacin and ornidazole by proposed RP-UPLC

\begin{tabular}{|l|l|l|l|l|l|l|}
\hline \multirow{2}{*}{ Suspension } & \multicolumn{2}{|c|}{ Label claim (per 10ml) } & \multicolumn{2}{c|}{ Amount found (per 10 ml) } & \multicolumn{2}{c|}{ \%Label claim } \\
\cline { 2 - 7 } & Levofloxacin & Ornidazole & levofloxacin & Ornidazole & levofloxacin & Ornidazole \\
\hline I & $125 \mathrm{mg}$ & $250 \mathrm{mg}$ & 124.7 & 249.8 & $99.76 \%$ & $99.92 \%$ \\
\hline
\end{tabular}

Table 5: Robustness study

\begin{tabular}{|l|l|l|l|l|}
\hline Conditions & \multicolumn{2}{|c|}{ RT (min) } & \multicolumn{2}{c|}{ Assay (\%) } \\
\hline Flow rate variation & Levofloxacin & ornidazole & Levofloxacin & ornidazole \\
\hline $0.43 \mathrm{ml} / \mathrm{min}$ & 0.542 & 0.946 & 99.67 & 99.45 \\
\hline $0.44 \mathrm{ml} / \mathrm{min}$ & 0.532 & 0.930 & 100.21 & 100.05 \\
\hline $0.45 \mathrm{ml} / \mathrm{min}$ & 0.516 & 0.902 & 99.51 & 99.82 \\
\hline Column : sample temperature & Levofloxacin & ornidazole & Levofloxacin & ornidazole \\
\hline $48^{\circ} \mathrm{C}: 20^{\circ} \mathrm{C}$ & 0.528 & 0.925 & 99.98 & 99.52 \\
\hline $48^{\circ} \mathrm{C}: 22^{\circ} \mathrm{C}$ & 0.528 & 0.924 & 100.24 & 99.85 \\
\hline $50^{\circ} \mathrm{C}: 20^{\circ} \mathrm{C}$ & 0.527 & 0.921 & 99.94 & 100.34 \\
\hline $50^{\circ} \mathrm{C}: 22^{\circ} \mathrm{C}$ & 0.527 & 0.921 & 99.52 & 99.67 \\
\hline $52^{\circ} \mathrm{C}: 20^{\circ} \mathrm{C}$ & 0.525 & 0.908 & 100.03 & 99.48 \\
\hline Different Analyst & Levofloxacin & ornidazole & Levofloxacin & ornidazole \\
\hline Analyst 1 & 0.525 & 0.912 & 100.35 & 99.56 \\
\hline Analyst 2 & 0.525 & 0.913 & 100.21 & 100.59 \\
\hline Analyst 3 & 0.524 & 0.912 & 99.58 & 99.94 \\
\hline Mobile Phase ratio (Buffer:ACN) & Levofloxacin & ornidazole & Levofloxacin & ornidazole \\
\hline $63: 37 \mathrm{~V} / \mathrm{V}$ & 0.511 & 0.870 & 99.62 & 99.24 \\
\hline $65: 35 \mathrm{~V} / \mathrm{V}$ & 0.526 & 0.920 & 99.56 & 99.75 \\
\hline $67: 33 \mathrm{~V} / \mathrm{V}$ & 0.546 & 0.980 & 100.05 & 99.27 \\
\hline
\end{tabular}

(Each determination is the outcome of 3 repeated injections)

\section{Specificity}

The specificity of the developed method was determined by injecting sample solutions which were prepared by forcibly degrading the sample in presence of stress conditions such as acid, base \& oxidative medium and application of light and heat. The stability signifying ability of the method was established from the acquired chromatographic data for Levofloxacin and Ornidazole. The results of force degradation study are explained in Table 6 .

Table 6: Specificity Study

\begin{tabular}{|l|l|l|l|}
\hline Stress condition & \multirow{2}{*}{ Time duration } & \multicolumn{2}{|c}{ \%Degradation } \\
\cline { 3 - 4 } & & Levofloxacin & Levofloxacin \\
\hline Acid degradation & 1 Hour & 27.65 & 19.43 \\
\hline Base degradation & 1 Hour & 25.80 & 54.16 \\
\hline Oxidative degradation & 1 Hour & 33.33 & 65.96 \\
\hline Thermal degradation & 1 Hour & 28.42 & 26.88 \\
\hline Photo degradation & 48 Hour & 23.61 & 35.86 \\
\hline
\end{tabular}

\section{Conclusion}

A stability indicating UPLC method has been developed and validated for the determination of Levofloxacin and Ornidazole in combined pharmaceutical dosage forms. The developed method was validated as per ICH guidelines and was found to be accurate, precise, robust, specific and less time consuming as compared to available methods. No interference from any components of pharmaceutical dosage form or degradation products was observed, and the method has been successfully used to perform rapid and accurate analysis of Levofloxacin and Ornidazole in their combined pharmaceutical dosage form.

\section{References}

[1]. S.B. Chepurwar, A.A. Shirkhedkar*, S.B. Bari, R.A. Fursule, and S.J. Surana : Validated HPTLC Method for Simultaneous Estimation of Levofloxacin Hemihydrate and Ornidazole in Pharmaceutical Dosage Form, Journal of Chromatographic Science, September 2007, Vol. 45.

[2]. Shafrose Syed, Haritha Pavani : Validated Simultaneous Estimation and Development of Levofloxacin and Ornidazole by RPHPLC Method, International Journal of Pharmaceutical and Clinical Research 2012; 4(4): 52-55, ISSN: 0975-1556.

[3]. Patel, Satish A; Prajapati, Arun M; Patel, Paresh U; Patel, Natubhai J; Vaghmasi, Jayesh B : Development and Validation of Column High-Performance Liquid Chromatographic and Derivative Spectrophotometric Methods for Determination of Levofloxacin and Ornidazole in Combined Dosage Forms, journal of association of official analytical chemists, Volume 91, Number 4, July 2008 , pp. 756-761(6).

[4]. Nagavalli, D.; Rajeevkumar, Rekha; Rajeev Kumar, P.; Devi, T.: Derivative Spectrophotometric Estimation of Levofloxacin hemihydrate and Ornidazole, International Journal of ChemTech Research, Oct2010, Vol. 2 Issue 4, p2145-2149.

[5]. FDA, ICH-Q1A (R2): Stability Testing Of New Drug SubstancesAnd Products, Vol. 68, U S Food And Drug Administration, Washington, DC, USA, 2nd Edition, 2003. 
[6]. FDA, ICH-Q1B: Photo-Stability Testing Of New Drug Sub-Stances And Products, Vol. 62, U S Food And Drug Administration, Washington, DC, USA, 1997.

[7]. FDA, ICH-Q2 (R1): Validation Of Analytical Procedures: Text And Methodology, Vol. 60, U S Food And Drug Administration, Washington, DC, USA, 1995.

[8]. United State Pharmacopoeia, The U.S. Pharmacopeia Convention, United State Pharmacopoeia, Rockville, Md, USA, 30 ${ }^{\text {th }}$ Edition, 2007. 